\title{
CEREBROSPINAL FLUID PRESSURE CHANGES DURING THE INDUCTION PHASE OF ANAESTHESIA
}

\author{
M.M. NAYAK, I.M. BALI, H. SINGH AND Y.K. BATRA
}

\begin{abstract}
Cerebrospinal fluid pressure (CSFP) by lumbar puncture, systemic blood pressure (BP) and pulse rate (PR) were measured for 15 minutes during the induction phase of general anaesthesia in seven groups of six healthy female patients each.

Intravenous drugs, thiopentone $5 \mathrm{mg} \cdot \mathrm{kg}^{-1}$, alfathesin $50 \mu 1 \cdot \mathrm{kg}^{-1}$ and diazepam $0.5 \mathrm{mg} \cdot \mathrm{kg}^{-1}$ given in 10 to 20 seconds caused a fall of CSFP and BP, whereas ketamine 2 $\mathrm{mg} \cdot \mathrm{kg}^{-1}$ and a three-minute induction with halothane three per cent, trichloroethylene one per cent, or methoxyflurane 0,75 per cent caused a sharp highly significant but short-lived rise of CSFP. Unlike ketamine, trichlorethylene and methoxyflurane, halothane caused a simultaneous significant fall of BP.

To rule out apprehension as the cause of the rise of CSFP with inhalation agents a second challenge was given with similar concentrations of the vapours while patients were asleep. These still produced a sharp and significant rise of CSFP.
\end{abstract}

ANAESTHETIC TECHNIQUES, especially in neurosurgical procedures, are generally aimed at ensuring a minimal change in the volume of any of the intracranial compartments. An increase in the intracranial volume is prevented by avoiding hypoxia, hypercarbia, straining, venous obstruction and drugs which are known to increase the cerebral blood flow and blood volume directly or indirectly by increasing the cerebral oxygen requirement.

The effect of anaesthesia on the cerebrospinal fluid pressure (CSFP) has been the object of many investigations and a simple yet effective method to monitor the changes of CSFP is by a lumbar puncture in patients who have no obstruction in the flow of CSF between the intracranial and spinal compartments.

It is suggested that many of the anaesthetic agents tend to increase the intracranial pressure (ICP) and this can be serious in patients where ICP is already raised. ${ }^{1-4}$ The present study was aimed at determining the effects of commonly used agents on the CSFP in a healthy normal adult population during the induction phase of general anaesthesia.

M.M. Nayak, M.D., Senior Resident; I.M. Bali, M.S. (Surg) M.S. (Anaesth), Ph.D., F.F.A.R.C.S., * Assistant Professor; H. Singh, D.A., M.S., M.A.M.S., Associate Professor; Y.K. Batra, M.D., M.N.A.M.S., Senior Resident. Department of Anaesthesiology, Post-Graduate Institute of Medical Education and Research, Chandigarh, India.

*Present address: Consultant Anaesthetist, Waveney Hospital, Ballymeana, Co. Antrim, N. Ireland.

\section{METHOD}

This study was carried out on 42 healthy patients undergoing tubal ligation who had agreed to participate. The mean age and weight of patients of different groups were comparable, as shown in Table I.

In the first part of the study anaesthesia was induced with a single intravenous dose of one of thiopentone $5 \mathrm{mg} \cdot \mathrm{kg}^{-1}$, ketamine $2 \mathrm{mg} \cdot \mathrm{kg}^{-1}$, alfathesin $50 \mu \mathrm{l} \cdot \mathrm{kg}^{-1}$, or diazepam $0.5 \mathrm{mg} \cdot \mathrm{kg}^{-1}$, in groups of six patients each. In the second part of the study three groups of six patients each received halothane three per cent, trichlorethylene one per cent or methoxylflurane 0.75 per cent given separately with a carrier gas mixture of 60 per cent nitrous oxide with oxygen.

The patients were placed in the lateral position and lumbar puncture was carried out at the $\mathrm{L}_{2}-\mathrm{L}_{3}$ interspace with a 21-gauge needle under proper aseptic precautions, following local infiltration with two per cent lidocaine. Air compressed manometer (monoject) was attached to the needle through a three-way connection and after three drops of cerebrospinal fluid had come out. CSFP was recorded when its reading became stable.

For the intravenous groups, keeping the patients in the lateral position, the precalculated dose of intravenous induction agent was given in a period of 10 to 20 seconds. CSFP, blood pressure and pulse rate were recorded at 30 seconds and then at every minute up to five minutes. Thereafter CSFP monitoring was continued every min- 
TABLE I

Mean Age and Body Weight of the Patients of THE DifFERENT GROUPS INDUCED WITH INTRAVENOUS AND INHALATIONAL INDUCTION AGENTS

\begin{tabular}{lcccc}
\hline \hline & \multicolumn{4}{c}{ Mean \pm SD } \\
\cline { 2 - 5 } \multicolumn{1}{c}{ Drug group } & Age (yrs) & Weight (kg) \\
\hline A. Intravenous & & & & \\
Thiopentone & 32.3 & $(6.55)$ & 49.8 & $(6.43)$ \\
Alfathesin & 31.8 & $(4.72)$ & 50.0 & $(7.3)$ \\
Ketamine & $29.2(2.29)$ & 48.8 & $(4.1)$ \\
Diazepam & $30.0(6.69)$ & 4.63 & $(5.77)$ \\
B. Inhalational & & & & \\
$\quad$ Halothane & $26.7(8.16)$ & 46.5 & $(13.86)$ \\
Trichlorethylene & $30.3(5.29)$ & 41.7 & $(6.05)$ \\
$\quad$ Methoxyflurane & $26.83(2.23)$ & 43.83 & $(5.27)$ \\
\hline
\end{tabular}

ute up to 15 minutes but pulse and blood pressure were recorded at 7,10 , and 15 minutes. Patients in the inhalational group received anaesthesia from a universal Blease vaporizer with the proper head for each inhalational agent. The concentration of each agent was raised to the desired level within one minute and continued for a further period of two minutes. The inhalational anaesthetic vapour was then withdrawn. Four minutes later nitrous oxide was discontinued and the flow of oxygen was increased to eight litres per minute. The sequence of events for both intravenous and inhalational agents is shown in Figure 1. A second challenge dose of inhalational anaesthetic agent was given to two patients of each group when CSFP became stabilized after the first three minutes of induction. During the second challenge dose only oxygen was used as the carrier gas. At the end of the study, regional analgesia with five per cent heavy lidocaine $1-1.5 \mathrm{ml}$ was given for the surgical procedure. Statistical significance was determined by Student's t-test applied to the CSFP, blood pressure and pulse rate changes in each group.

\section{ResUlts}

The mean changes in CSFP, blood pressure and pulse rate with the different intravenous and inhalational agents are represented graphically in relation to time in Figures $2-5$.

Thiopentone caused a definite fall of CSFP. This was well sustained and attained statistical significance at third and fourth minute after induction $(p<0.05$ ). The mean peak fall was $1.01 \pm$ $0.15 \mathrm{kPa}\left(10.3 \pm 1.54 \mathrm{~cm} \mathrm{H}_{2} \mathrm{O}\right)$. The mean peak fall of blood pressure was $1.82 \pm 0.28 \mathrm{kPa}(13.7 \pm$

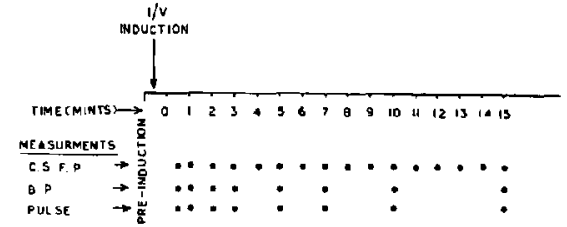

INHAL ATIONAL

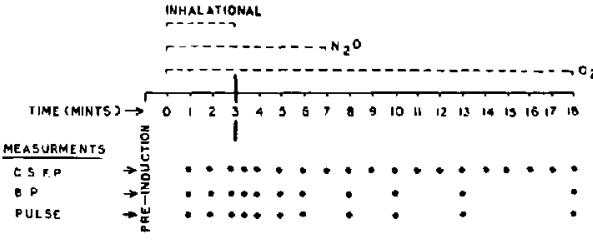

Figure 1 Time sequence of events during induction with intravenous and inhalational agents and observations of CSFP, blood pressure and pulse rate.

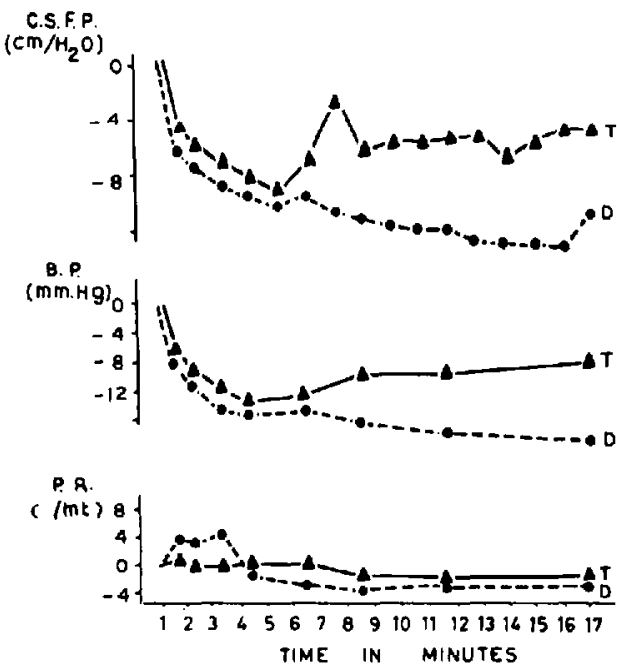

FIGURE 2 Mean changes of CSF pressure, mean blood pressure and pulse rate from pre-induction values following thiopentone (T) and diazepam (D) induction.

$2.14 \mathrm{~mm} \mathrm{Hg}$ ) which was also statistically significant ( $\mathrm{p}<0.01)$ as listed in Table II.

Administration of diazepam resulted in a steady and persistent fall of CSFP which became statistically significant at 9 minutes and remained so till the 14th minute after induction (Table II). The mean peak fall was $1.25 \pm 0.12 \mathrm{kPa}(12.7 \pm$ $1.25 \mathrm{~cm} \mathrm{H} \mathrm{H}_{2} \mathrm{O}$ ). Diazepam induction did not produce any evident variation in pulse rate but the mean peak fall of blood pressure observed was $2.49 \mathrm{kPa}$ (18.7 $\mathrm{mm} \mathrm{Hg}$ ) (Table III).

Smooth induction with alfathesin resulted in a persistent fall of CSFP in two patients in whom no 


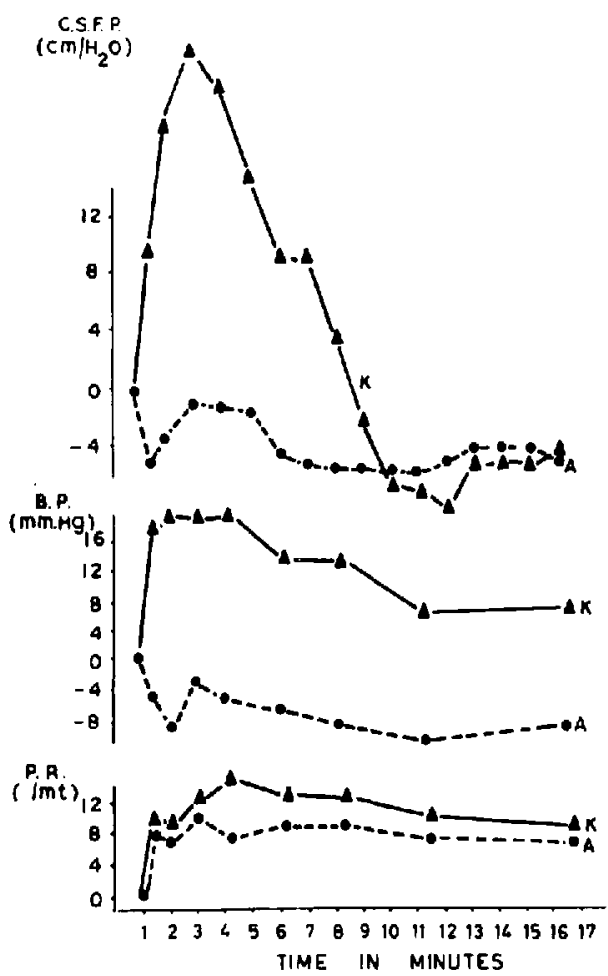

Figure 3 Mean changes of CSF pressure, mean blood pressure and pulse rate, from pre-induction values observed following ketamine $(K)$ and alfathesin $(A)$ induction.

complications developed. In the other four patients there was a rise in CSFP at different time intervals and these increases corresponded with the time of development of complications such as coughing. muscle rigidity and muscle tremors. The mean peak fall of $0.18 \pm 0.27 \mathrm{kPa}(1.83 \pm 2.79$ $\mathrm{cm} \mathrm{H}_{2} \mathrm{O}$ ) was not statistically significant. Mean peak fall of blood pressure of $1.22 \pm 0.78 \mathrm{kPa}$ $(9.17 \pm 5.89 \mathrm{~mm} \mathrm{Hg}$ ) and changes of pulse rate after induction with alfathesin were also not significant (Table III).

Ketamine caused a marked rise in CSFP for the first four to six minutes and these increased val. ues came down to or near to pre-anaesthetic levels within ten minutes after induction (Figure 3). Mean peak rise of $2.60 \pm 0.38 \mathrm{kPa}(26.5 \pm 3.88$ $\mathrm{cm} \mathrm{H}_{2} \mathrm{O}$ ) was observed and this was highly significant $(p<0.01)$. Ketamine also caused an increase in pulse rate and blood pressure which were found to be statistically highly significant $(\mathrm{p}<0.0$ I) (Table III).

Administration of halothane caused a definite rise in CSFP during the induction period and

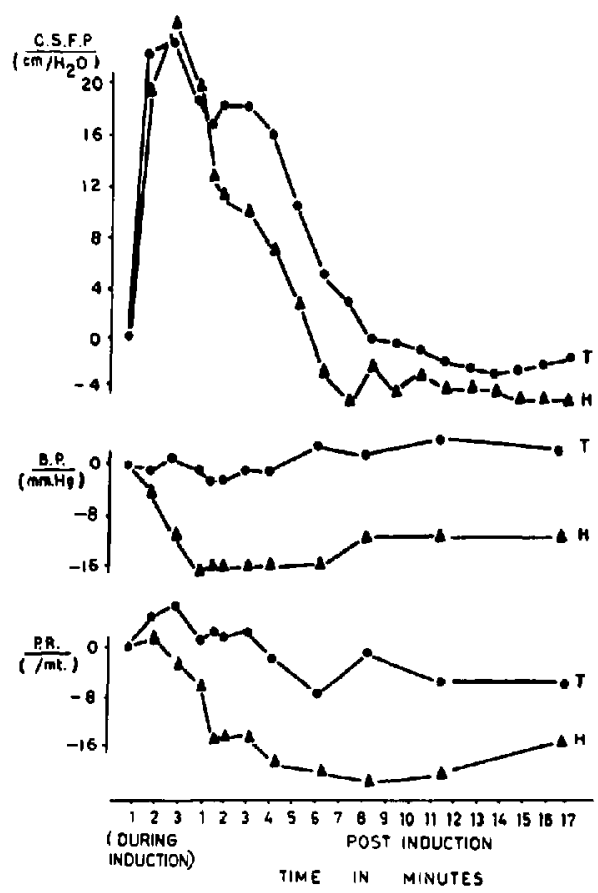

Figure 4 Mean changes of CSF pressure, mean blood pressure and pulse rate following 1richlorethylene $(\mathrm{T})$ and halothane $(\mathrm{H})$ induction.

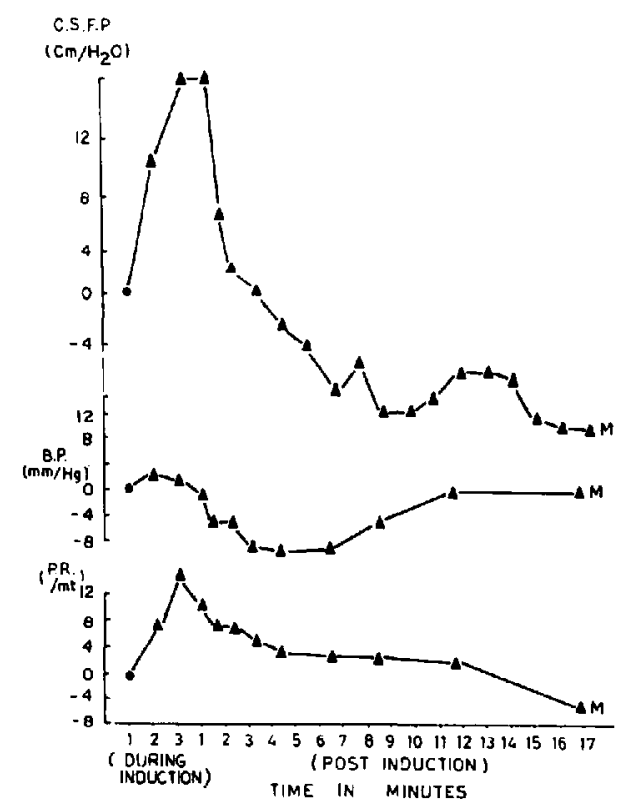

Figure 5 Mean changes of CSF pressure, mean blood pressure and pulse rate following methoxyflurane (M) induction. 


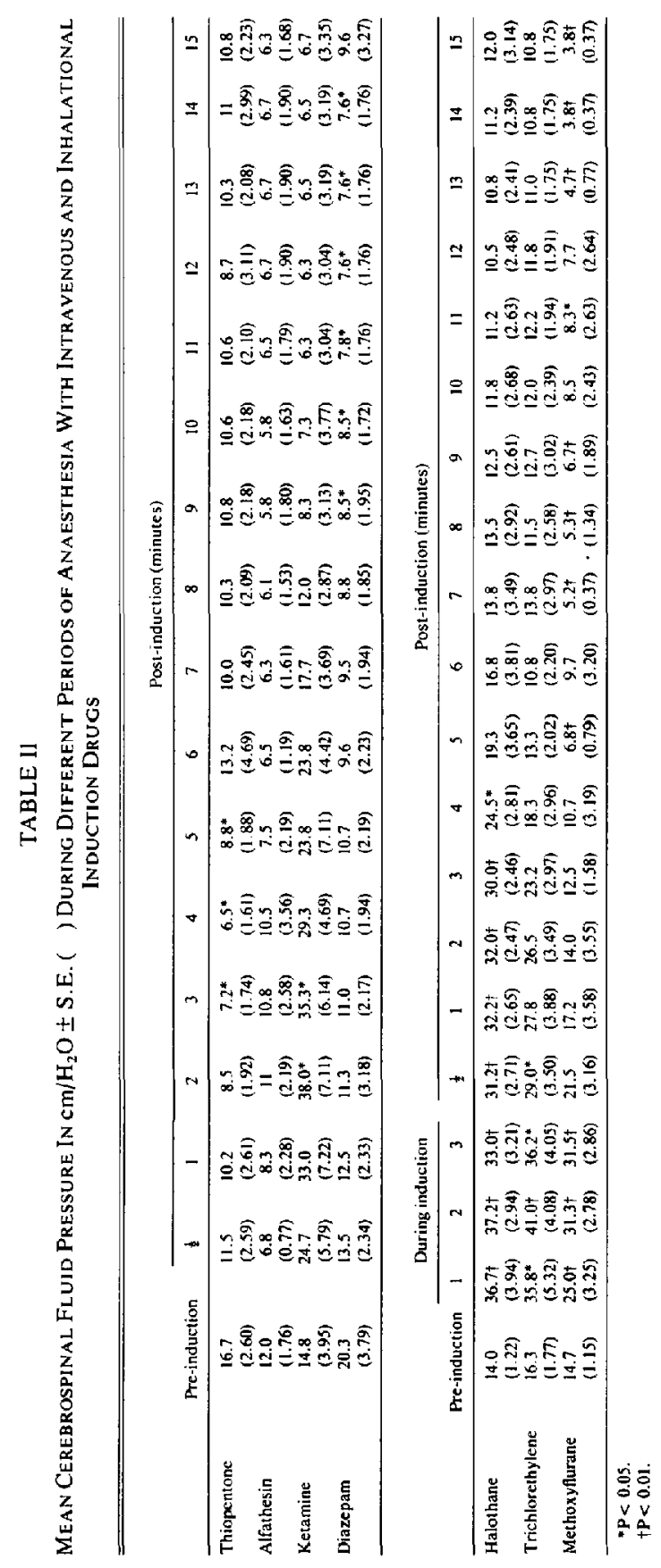


TABLE III

Mean Peak Changes of CSF Pressure, Blood Pressure and Pulse Rate in Patients Induced With Intravenous AND INHALATIONAL AGENTS

\begin{tabular}{lccc}
\hline \hline & \multicolumn{3}{c}{ Mean peak changes ( \pm SE) } \\
\cline { 2 - 4 } & \multicolumn{3}{c}{ Mean blood } \\
Dressure & Pulse rate \\
Drugs groups & $\begin{array}{c}\text { CSF pressure } \\
\left(\mathrm{cm} / \mathrm{H}_{2} \mathrm{O}\right)\end{array}$ & $\begin{array}{c}\text { (mm/Hg) } \\
\text { (beats/mt) }\end{array}$ \\
\hline A. Intravenous & & & \\
Thiopentone & $-10.33^{*}$ & $-13.7 \dagger$ & +2.0 \\
Alfathesin & $(1.54)$ & $(2.14)$ & $(4.67)$ \\
& -1.83 & -9.17 & +10.3 \\
Ketamine & $(2.79)$ & $(5.89)$ & $(7.94)$ \\
& $+26.55 \dagger$ & $+24.33 \dagger$ & $+17 \dagger$ \\
Diazepam & $(3.88)$ & $(3.48)$ & $(3.72)$ \\
& $-12.7 \dagger$ & $-18.7 \dagger$ & +2.3 \\
B. Inhalational & $(1.25)$ & $(3.91)$ & $(7.86)$ \\
Halothane & & & \\
& $+25.5 \dagger$ & $-20.5 \dagger$ & $-26 \dagger$ \\
Trichlorethylene & $(1.94)$ & $(1.89)$ & $(4.88)$ \\
& $+26 \dagger$ & +0.17 & +2.0 \\
Methoxyflurane & $(2.62)$ & $(7.73)$ & $(11.41)$ \\
& $+19.2 \dagger$ & -8.2 & $+17.3 \dagger$ \\
& $(2.02)$ & $(4.05)$ & $(3.45)$ \\
\hline
\end{tabular}

*Statistically significant $\mathrm{p}<0.05$.

†Statistically highly significant $p<0.01$.

these raised values returned to base line or to slightly lower levels within seven minutes in the post-induction period. Mean maximum rise in CSFP during induction with this agent was 3.65 $\mathrm{kPa}\left(37.2 \mathrm{~cm} \mathrm{H}_{2} \mathrm{O}\right.$ ) (Table II) and statistically this rise was highly significant $(p<0.01)$. The second challenge with halothane three per cent in oxygen also caused a slow and definite rise in CSFP (Figure 6). Halothane induction caused a fall in both blood pressure and pulse rate which was also highly significant $(p<0.01)$.

CSFP rose sharply on the introduction of trichlorethylene and the increased values came down to below pre-anaesthetic levels within five minutes in the post-induction period. Mean maximum rise in CSFP observed during induction was $4.02 \mathrm{kPa}\left(41 \mathrm{~cm} / \mathrm{H}_{2} \mathrm{O}\right.$ ) (Table II) while the mean peak change was $2.55 \pm 0.26 \mathrm{kPa}$ ( $26 \pm$ $2.62 \mathrm{~cm} \mathrm{H}_{2} \mathrm{O}$ ). The second challenge with trichlorethylene one per cent in oxygen also caused a rise in CSFP in both patients. Blood pressure and pulse rate changes at all times were not significant.

Following administration of methoxyflurane, the CSFP rose by a mean peak value of $1.88 \pm 0.2$ $\mathrm{kPa}\left(19.2 \pm 2.02 \mathrm{~cm} \mathrm{H} \mathrm{H}_{2} \mathrm{O}\right)$. This rise returned to and then fell below the pre-anaesthetic value within six minutes after induction (Table II and Figure 5). CSFP went up during the second chal- lenge with 0.75 per cent methoxyflurane in oxygen but came down to pre-induction within five minutes. Mean peak fall of blood pressure was $1.09 \pm 0.54 \mathrm{kPa}(8.2 \pm 4.05 \mathrm{~mm} \mathrm{Hg})$ which was not statistically significant.

\section{Discussion}

The study demonstrates that in a normal healthy adult population intravenous induction with thiopentone, diazepam and alfathesin causes a fall in CSFP, whereas ketamine and inhalational induction with halothane, trichlorethylene or methoxyflurane cause a sharp rise of CSFP.

Although there is a wide range of opinion on this subject in the literature ${ }^{5.6}$ the reasons for the effects are generally attributed to changes in cerebral blood flow, ${ }^{7}$ cerebral metabolism and cerebral consumption of oxygen. Hunter observed excellent to good dural relaxation with continuous thiopentone infusion in neurosurgical patients and attributed this to a lowering of CSFP. Although Shapiro and his colleagues observed similar reductions in patients with raised intracranial pressure they were unable to demonstrate a fall of CSFP in normal patients. ${ }^{9}$

Though there is no reported study on diazepam, the similarity of fall in the CSFP and 


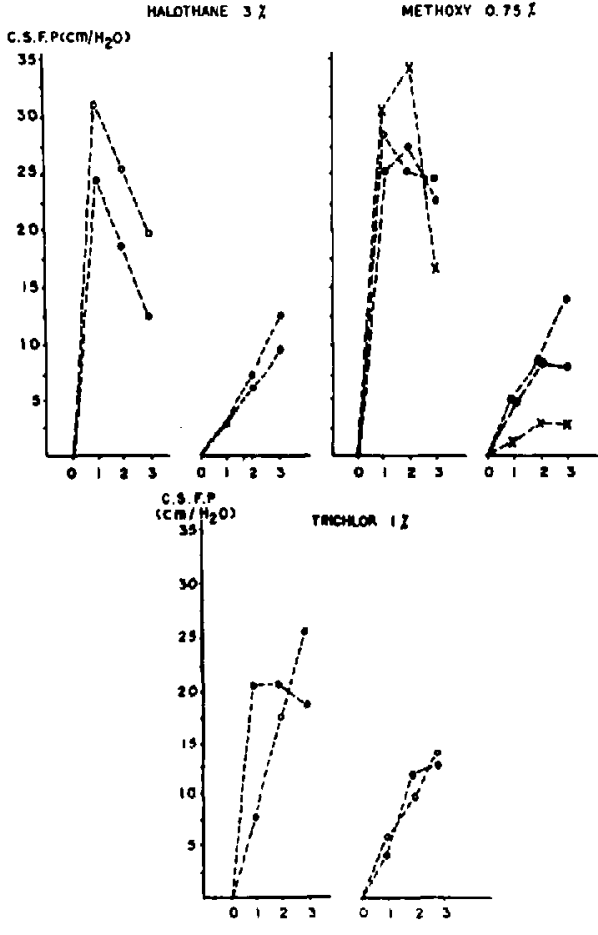

Figure 6 Comparative mean CSF pressure changes during three minutes induction (left side graph) and three minutes second challenge (right side graph) with halothane ( 3 per cent), trichlorethylene ( 1 per cent) and methoxyflurane $(0.75$ per cent $)$ in individual patients.

blood pressure to that with thiopentone could be due to a reduction of brain metabolism and oxygen consumption, aided by a fall in cerebral blood flow because of lowering of the mean systemic arterial pressure as a result of peripheral vasodilatation and venous pooling.

The results of alfathesin induction have shown insignificant changes of CSFP, even though the mean blood pressure showed a slight fall. We attribute this to the high incidence (four patients out of six) developing complications of cough, tremor and muscle rigidity. ${ }^{10}$ Pickerdot, $, 1,12$ and his associates have earlier described a fall in CSFP after alfathesin in animals to be due to a depression of cerebral metabolism and falling blood pressure, resulting in a fall in cerebral blood volume. However, two patients in the present series who did not have induction complications behaved in a way similar to thiopentone and diazepam patients.

The sharp and short-lived increase in the CSFP with ketamine could be because of increased muscle tone and a rise in systemic blood pressure, resulting in a sharp increase in cerebral blood flow during induction. The disparity between the present work and that of others ${ }^{13,14,15}$ on the duration of rise in CSFP after ketamine induction could be because no halothane was used with carrier gas. Halothane of itself causes a sharp and prolonged rise in CSFP as shown in the present work.

Various authors ${ }^{2,16,17}$ have demonstrated clearly that halothane in anaesthetic concentration almost invariably increases CSFP. This is attributed to an increase in cerebral blood flow despite a fall in systemic blood pressure; although the rise was transient and would in due course be correct by the re-adjustment of the various intracranial compartments. Similar results were obtained with all three inhalation agents, halothane, trichlorethylene and methoxyflurane. To rule out the possibility of apprehension in patients because of the mask and inhalation of gases two patients in each of the halothane and trichlorethylene groups received a second challenge with the inhalational agents with the background carrier gas as 100 per cent oxygen. This resulted again in a sharp rise in all cases, although not of a magnitude similar to the first challenge (Figure 6). This rules out the possibility of apprehension as the major factor and clearly defines a direct effect of inhalation vapours on

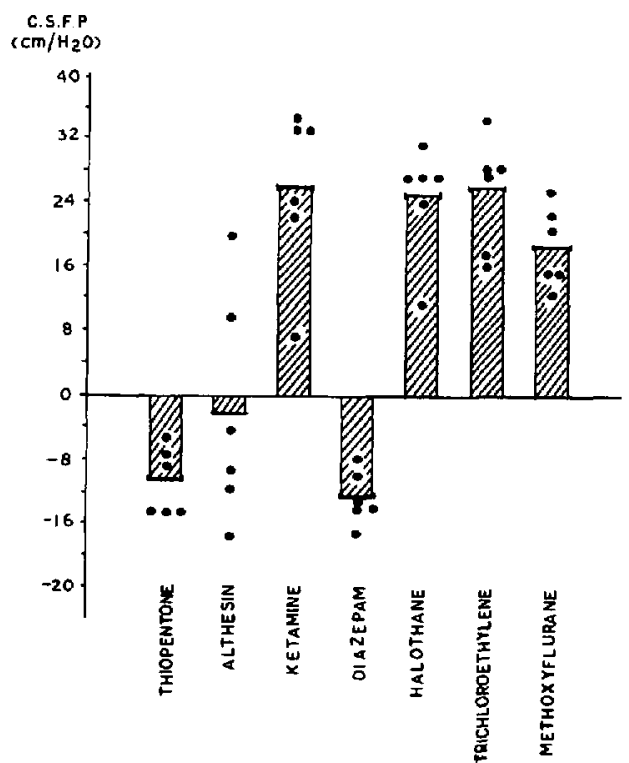

Figure 7 Mean peak changes and scatter of peak changes in seven drug groups of six patients each. 
CSFP. The quick and early rise of CSFP in the first two or three minutes of induction with no clinical evidence of retention of carbon dioxide or hypoventilation rule out the possibility of the effects being due to carbon dioxide retention, although no samples were taken for blood gas analysis.

The striking difference between the effects of intravenous induction agents and inhalation agents on CSFP (Figure 7) could be of importance to anaesthetists dealing with neurosurgical patients.

\section{ACKNOWLEDGEMENTS}

The authors would like to thank Prof. P.K. Devi and Dr. I.G. Mahajan, Department of Obstetrics and Gynaecology for permission to study the patients.

\section{REFERENCES}

1. HEwER, A.J.H. Intracranial pressure and its implications in neuroanaesthesia. In General Anaesthesia, ed. Gray, T.C. \& Nunn, J.F. London, Butterworth, pp. 320 (1971).

2. McDowall. D.G.. Barker. J. \& Jennet. W.B Cerebrospinal fluid pressure measurements during anacsthesia. Anaesthesia 2I: 189 (1966).

3. Henriksen, H.T. \& Jorgensen, P.B. The effect of nitrous oxide on intracranial pressure in patients with space occupying lesions. Lancet $1: 61$ (1969).

4. Lockhart, C.H. \& JeNkins, J. J. Ketamine induced apnoea in patients with raised intracranial pressure. Anesthesiology 37:92 (1972).

5. ShapiRo, H.M. Intracranial hypertension. Anesthesiology 43: 444 (1975).

6. JENNET, W.B., Barker, J.. Fitch, W. \& MCDOWALL. D.G. Effect of anaesthesia on intracranial pressure in patients with space-occupying lesions. Lancet $/: 61$ (1969).

7. Rich, M., Scheinaerg, P. \& Belle, M.S. Re lationship between cerebrospinal fluid pressure changes and cerebral blood flow. Circulat. Res. I: 389 (1953).

8. Hunter, A.R. Thiopentone supplemented anaesthesia for neurosurgery. Brit. J. Anaesth. 44: 506 (1972).

9. Shapiro, H.M. Galindo, A., Wyte, S.R. \& HARRIS, A.B. Rapid intra-operative reduction of intracranial pressure with thiopentone. Brit. J. Anaesth. 45: 1057 (1973)

10. Clarke, R.S.J., Dundee, J.W. \& Cakson, I.W. Some aspects of the clinical pharmacology of althesin. Post Grad. Med. J. 48: 62 (1972).

11. Pickeront, V.W.A., McDowall, D.G., Coroneos, M.H. \& KeaneY, N.P. Effect of althesin on cerebral perfusion, cerebral metabolism and intracranial pressure. Brit. J. Anaesth. 44: 751 (1972).

12. Pickerodt, V.W.A., McDowall, D.G., Coroneos, M.H. \& Keanley. N.P. Effect of althesin on carotid blood flow and intracranial pressure in the anaesthetized baboon. Postgrad. Med. J. 48: 58 (1972).

13. Gardner, A.E., Olson, B.E. \& Lichtiger. M. Cerebrospinal fluid pressure during dissociative anaesthesia with ketamine, Anesthesiology 35: 226 (1971).

14. Sari. A. Okuda, Y. \& Tekeshita, H. The effect of ketamine on cerebrospinal fluid pressure. Anesth. Analg. (Curr. Res.) 51: 560 (1972).

15. DAwson, B., Michen Felder, J.D. \& Theye. R.A. Effects of ketamine on canine cerebral blood flow and metabolism: modification by prior administration of thiopentol. Anesth. Analg. (Curr. Res.) 50: 443 (1971).

16. McDowall, D.G. The effect of clinical concentration of halothane on the blood flow and oxygen uptake of the cerebral cortex. Brit. J. Anaesth. 39: $186(1967)$.

17. MCDowall, D.G., Harper, A.M. \& Jacobson. I. Cerebral blood flow during halothane anaesthesia. Brit. J. Anaesth. 35: 394 (1963).

18. McDowal.I, D.G., Harper, A.M. \& Jacobson. I. Cerebral blood flow during trichlorethylene anaesthesia. Brit. J. Anaesth. 36: 11 (1964).

19. Gkay, I.G., Mitra, S.K., Nishett, H.I.A. Aspin, N. \& CrFighton, R.E. The effect of methoxyflurane on cerebral blood flow in the dog. Canad. Anaesth. Soc. J. 18: 408 (1971).

\section{RÉSUMÉ}

On a mesuré la pression du liquide céphalo-rachidien (par ponction lombaire), ainsi que la pression artérielle et la fréquence cardiaque durant 15 minutes lors de l'induction de l'anesthésie chez 42 patientes en bonne santé. Pour les conditions de l'étude, on avait formé sept groupes de six patients chacun, chaque groupe étant assigné à un agent différent. Le thiopental à la dose de $5 \mathrm{mg} \cdot \mathrm{kg}^{-1}$, l'alfathésin à $50 \mu \mathrm{l} \cdot \mathrm{kg}^{-1}$, ainsi que le diazépam à $0.5 \mathrm{mg} \cdot \mathrm{kg}^{-1}$ administrés en 10 à 20 secondes, produisaient une chute de pression du LCR et de la pression artérielle, alors que la kétamine à la dose de $2 \mathrm{mg} \cdot \mathrm{kg}^{-1}$, de même qu'une induction par inhalation de trois minutes à I'halothane à 3 pour cent, au trichloroéthylène à 1.0 pour cent ou au méthoxyflurane à 0.75 pour cent, amenajent une élévation aiguë et hautement significative, mais de courte durée, de la pression du liquide céphalo-rachidien. Le trichloroêthylène, l'halothane et le méthoxyflurane provoquaient une chute simultanée significative de la pression artérielle. Dans le but d'éliminer l'appréhension comme cause de l'élévation de tension du LCR chez les patientes induites avec un agent d'inhalation, on a répété l'administration de ces mêmes agents d'inhalation, aux mêmes concentrations, après stabilisation de l'anesthésie. On a pu observer la mêmé élévation aiguë et transitoire de la pression du LCR. 